\title{
DÜBLIN
}

Technological University Dublin

ARROW@TU Dublin

Articles

TU Dublin Professional Services (including

Library Services)

2018

\section{Academic Twitter and Professional Learning: Myths and Realities}

Muireann OKeeffe

Technological University Dublin, muireann.okeeffe@tudublin.ie

Follow this and additional works at: https://arrow.tudublin.ie/libart

Part of the Curriculum and Instruction Commons, Educational Methods Commons, and the Higher Education Commons

\section{Recommended Citation}

Muireann O'Keeffe (2018) Academic Twitter and professional learning: myths and realities, International Journal for Academic Development, DOI: 10.1080/1360144X.2018.1520109

This Article is brought to you for free and open access by the TU Dublin Professional Services (including Library Services) at ARROW@TU Dublin. It has been accepted for inclusion in Articles by an authorized administrator of ARROW@TU Dublin. For more information, please contact arrow.admin@tudublin.ie, aisling.coyne@tudublin.ie, gerard.connolly@tudublin.ie.

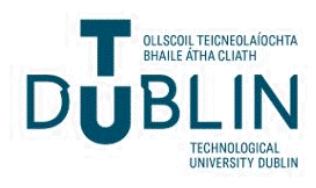




\section{International Journal for Academic Development}

\section{(1)}

\section{Academic Twitter and professional learning: myths and realities}

\section{Muireann O'Keeffe}

To cite this article: Muireann O'Keeffe (2018): Academic Twitter and professional learning: myths and realities, International Journal for Academic Development, DOI: 10.1080/1360144X.2018.1520109

To link to this article: https://doi.org/10.1080/1360144X.2018.1520109

\section{册 Published online: 01 Oct 2018.}

Submit your article to this journal $\pi$

山 Article views: 62

View Crossmark data ¿ 


\section{Academic Twitter and professional learning: myths and realities}

\section{Muireann O'Keeffe (iD}

Learning, Teaching and Technology Centre, Dublin Institute of Technology, Dublin, Ireland

\begin{abstract}
Social networking sites provide opportunities for informal and social learning of academic practices in higher education, yet not all academics engage in these spaces. This qualitative study suggests that while Twitter offers informal opportunities for academic development, inhibiting factors prevent staff from establishing their social presence and participating in conversations on academic Twitter. In a pervasively digital era, rethinking academic development practices is required to build digital capacity and digital identity of staff to support participation on social networking sites for academic learning and development.
\end{abstract}

\section{ARTICLE HISTORY}

Received 14 August 2017

Accepted 30 May 2018

\section{KEYWORDS}

Academic development; digital capacity; informal learning; social media; Twitter

\section{Introduction}

The social networking site Twitter is an influential space where academics share and discuss practice, which thereby has the potential of contributing to the development of such practice in higher education (Costa, 2013; McPherson, Budge, \& Lemon, 2015; Stewart, 2016; Veletsianos, 2012). While many studies tend to focus on the benefits that social networking sites offer to academic practice, they fail to capture the wide range of experiences, including the concerns of staff using them. Common assumptions are that higher education staff, with appropriate digital and technical skills, can participate on social networking sites for the purpose of developing academic practice. However, as some have pointed out (Beetham, 2015; Lupton, Mewburn, \& Thomson, 2018), the factors that enable participation on social networking sites are more nuanced than merely acquiring technical skills. To bridge the gap in current research, this paper focuses on the lesser heard concerns of staff, exploring in particular their experiences of Twitter for the purpose of informal learning and academic development. The experiences highlighted here provide important insights into how in a pervasively digital era, the scope of academic development needs to reconceptualise the digital development needs of higher education staff.

\section{Study background}

Academic development is generally concerned with how staff in higher education enhance teaching and learning practices (Boon, Matthew, \& Sheward, 2010; Gibbs, 2013; Higgs \& 
McCarthy, 2008; Leibowitz, 2014; Linder \& Felten, 2015). To this end, it is recognised that those involved in teaching roles benefit from learning and development activities which, in turn, helps to support successful student learning (Rienties \& Hosein, 2015). Yet, time-poor staff have been unable to wholly partake in formal opportunities for professional learning, resulting in calls for alternative, flexible, and informal learning opportunities (Mårtensson \& Roxå, 2015; Slowey, Kozina, \& Tan, 2014). Informal learning is conceived as social energy shaped by opportunities for engagement in solving problems of practice (Eraut, 1994; Marsick \& Watkins, 1990). Conversations with colleagues, sharing research at conferences, reading articles, preparing articles for publication, workshops, seminars, and participating on social networking sites are all considered informal learning opportunities for academic development (National Forum, 2015).

Twitter enables individuals to create their own unique networks, making virtual discussions about professional practice possible. Indeed, staff in higher education use Twitter for various research, networking, learning, and identity development activities (Costa, 2014; Pasquini, 2015; Stewart, 2015; Veletsianos, 2012). At the same time, some researchers consider Twitter unfit for academic purposes (Fransman, 2013), with others classifying it as a marketing tool (Rinaldo, Tapp, \& Laverie, 2011). Despite various criticisms, in the main Twitter has been endorsed for academic learning (Beckingham, 2015) as enabling connections that reach beyond local higher education settings (McPherson et al., 2015) while facilitating personalised and just-in-time forms of learning (Carpenter \& Krutka, 2014; Gerstein, 2011; Pearce, Weller, Scanlon, \& Kinsley, 2010).

While Twitter has become commonly accepted as an informal academic learning space, more thoughtful attention to how staff use such technologies is needed (Oliver, 2013; Selwyn, 2013). Additionally, as academic developers we need to develop greater awareness of how staff are equipped to participate on social networking sites. Some studies have quantified and measured the purposes and benefits of social networks for higher education (Lupton, 2014; Veletsianos \& Kimmons, 2012), but many of these studies have failed to demonstrate how social networks, such as Twitter, are experienced by higher education staff. To fill this gap, in this paper I explore the use of Twitter for the purpose of academic development to draw attention to the challenges faced by staff when using it. The research was led by the following questions:

- What are the experiences of staff using Twitter for informal learning and development of academic practices?

- What are the barriers experienced by staff using Twitter for informal academic development and learning?

\section{Exploratory research}

In this research, I sought to establish how higher education staff routinely use Twitter and investigate the barriers they experience in doing so. In exploring these questions, I aimed to provide recommendations for future academic practice by revealing 'possible lines of action' (Biesta, 2007, p. 16). The case study approach was chosen to illustrate the range of experiences of staff using Twitter, and to facilitate critical reflection and interpretation. Seven case studies explored the experiences of higher education staff using Twitter for 
informal learning (O'Keeffe, 2016). The study was designed ethically to prevent harm to participants, case descriptions were anonymised to protect confidentiality, and dissenting opinions of participants were respected (Bergold \& Thomas, 2012).

Participants, who were recruited via links to an academic development programme, comprised both lecturers $(n=3)$ and professional staff involved in academic development and learning technology roles $(n=4)$. Each of the seven participants represented a case. Thus, seven case descriptions (Miles, Huberman, \& Saldana, 2014) were produced using semi-structured interviews exploring participants' use of Twitter for informal learning and academic development purposes. Prior to researcher interpretation, each participant reviewed and confirmed their case description.

Next, I used thematic analysis (Braun \& Clarke, 2006) to generate and define themes from each participant. I produced a case display table (Miles et al., 2014) that summarised central themes from each case description, enabling the identification of similar and divergent themes across the cases. This paper highlights the following themes that arose across the case studies: confidence, vulnerability, belonging, and capacity to participate on academic Twitter.

\section{Findings}

In the interviews, participants commonly claimed that social and informal learning was key to their academic learning and development. Coupled with this, Twitter was regarded as an informal and accessible means to stay abreast of advances in education and practice, which echoes findings of other research (Holmes, Preston, Shaw, \& Buchanan, 2013; Krutk \& Carpenter, 2014; Skyring, 2013).

However, what was most interesting is that while advocating social and informal modes of learning, each participant used Twitter in unique ways. Some participants exhibited a high level of participation on Twitter, establishing social presence by posting regularly and communicating with others online, while others preferred to observe online posts and conversations, rather than actively participating in virtual discussions. Indeed, this study found that some participants completely avoided establishing social presence or interacting with others on Twitter.

Much of the literature related to professional learning acknowledges the social nature of learning through networks and communities (Dochy, Gijbels, Segers, \& Van Den Bossche, 2011; Eraut, 1994). Similarly, the community of practice model (Wenger, 1998) values involvement in communities, enabling novices to connect with advanced practitioners and supporting learning through participation. Findings here demonstrate that although participants considered Twitter a means for social and informal learning, their routine actions did not involve overt social participation on Twitter; instead, they remained at the peripheries of online communities. The data revealed inhibiting factors, which are explained next.

\section{Confidence: 'I'm not confident about it being open'}

Maurice, a lecturer with 10 years' experience and a qualification in learning and teaching, had professional confidence that underpinned his capacity to post about academic practice on Twitter: 
I suppose it's a subject I feel very confident in, but because a lot of the people in this area, which is $\mathrm{X}$ education, are X lecturers who are interested in the topic but maybe have not engaged in it in an academic sense, by which I mean like you know literature or having done courses or whatever. I'm not putting myself up here but I'm just saying I am informed.

Maurice had posted tweets, thereby establishing social presence that enabled his participation on Twitter communities. However, he was aware that other professionals might be more hesitant about posting online:

I suppose people would be perhaps cautious that they may say something silly, misrepresent the institution, misrepresent themselves.

Paul, an early career lecturer, confirmed Maurice's hunch, suggesting that he did not post on Twitter due to a perceived knowledge and status gap between him and other academic tweeters. He reasoned that 'people I subscribe to are kind of fairly high up'. Coupled with this, he preferred reading the Twitter stream to posting:

It's in my nature, I like to kind of stand back and just observe [laughs] and, I don't know whether I'd have ... I wouldn't feel ready to have a ... but in a way having an opinion or something.

Similarly, Denise, a learning technologist, claimed that Twitter was for:

Colleagues who know a lot more than I do in an area and just watching what they do, the strategies they employ.

Although Denise avoided posting on Twitter, she posted and shared information among a private Google group of colleagues. Within this private community, she felt safe to share her practice, knowledge, and opinions:

I'm not sure what it is about me that I'm not confident about it being massively open, the social media, but if I know who I'm talking to I'd be more confident about saying it, about tweeting something...

Denise had confidence expressing her professional knowledge among colleagues, with whom she had established relationships, but among unknown online Twitter audiences she was hesitant to post. This resonates with Hughes's (2010) concept of 'knowledgerelated identity congruence' (p. 47). Denise did not feel her professional knowledge was consistent with the knowledge of other education professionals using Twitter; she, therefore, preferred to read the Twitter stream rather than participate by posting or having conversations with others on Twitter.

Matt, who works in an academic development role, suggested that efficacy in navigating Twitter was important and recommended that some staff might need assistance to demystify participating on Twitter:

It may be a bit more of a challenge, just breaking down the fear factor, knowing how to actually use it.

Indeed, others have noted that engaging online requires the development of new styles of informal and rapid communication, cultural practices that run counter to formal academia (Lupton et al., 2018).

Data from Maurice, Paul, Denise, and Matt raise interesting points about the confidence necessary for participation in communities on Twitter. For Maurice, 
confidence in his professional knowledge enabled posting on Twitter. In contrast, Denise and Paul perceived gaps in their knowledge and status, which inhibited them from posting. Furthermore, for Matt, knowing the conventions of online communication on Twitter was vital.

\section{Vulnerability and risk: 'that poor woman, to have seen Twitter at that time'}

Carol, a learning technologist, recognised that tweets became long-lasting records of opinions online:

I hate not being able to edit tweets, I absolutely hate that, so that would certainly be a barrier in that I think I would agonise over tweets for too long before sending them.

This perception made her apprehensive about posting on Twitter, which is congruent with other research that notes the vulnerability and sensitivity that can be experienced when doing so (Stewart, 2015). Similarly, Denise liked to read posts on Twitter but chose not to participate in online conversations, mentioning 'I don't have that bravery', thereby indicating her feelings of vulnerability.

The potential for negative criticism on Twitter concerned Denise. She was 'hypersensitive' and worried that other professionals could negatively judge her posts in the online space. She described an email to all staff at her university, which triggered unwarranted criticism from university peers. This negative experience affected her subsequent online actions and she chose not to post work-related comments online. Denise acknowledged the importance of critiquing academic work practices, but felt that criticism could sometimes be delivered in unconstructive ways online.

Additionally, Denise witnessed a destructive Twitter event at a conference, when a sales person made a pitch to delegates, prompting unpleasant tweets:

It was just going so downhill, it really turned into a very destructive ... it ended up being a product pitch which seemed to irk a lot of people and people got ... people would rant ... that poor woman, to have seen Twitter at that point in time.

For Denise, these incidents confirmed the potentially damaging power of posting on Twitter. She feared becoming the target of similar abuse, leading to her reluctance to express herself online. Similarly, boyd (2009, 2014) writes about experiences of hostility on Twitter and questions how social networks can be effectively and constructively used, while limiting situations that contribute to vulnerability and potential abuse.

\section{Belonging and identity: 'you don't feel like you have that personal relationship'}

Referring to face-to-face professional learning, Paul said:

I guess because you've a very one-to-one or you've a relationship with the people, you know they're in the same class or same group, where in Twitter you don't feel you have that personal relationship.

In face-to-face contexts, Paul valued exchanging information and learning from others, and felt affinity with academic staff. However, he did not have close relationships with peers on Twitter, implying the challenges of establishing relationships online. In part, this 
was due to Paul's absence of knowledge congruence with other professionals on Twitter. In this regard, Wenger (1998) describes how a negative picture of one's position can affect participation in communities. So, it seems that Paul's self-perception of his knowledge and status limited the development of his social presence on Twitter, preventing him from developing relationships and establishing belonging in online communities.

In contrast, Maurice referred to his regular social interaction on Twitter for educational and non-educational purposes:

The way I approach Twitter is professionally with, maybe, a personal twist.

Maurice developed connections and instigated conversations with others on Twitter; this participation contributed to the development of his identity in online communities. As a consequence, Maurice became recognised as a knowledgeable educator and was invited to write articles for websites and periodicals about teaching in his discipline.

Similarly, Ben discussed making connections via Twitter with staff beyond his institution, prompting inter-university teaching and learning collaborations. By posting on Twitter, Maurice and Ben had become known to others, thus opening up professional conversations on teaching and learning. Maurice was of the view that he had cultivated a sense of belonging in communities on Twitter that offset professional isolation, a finding that resonates with other perceptions of Twitter as a virtual staffroom (Lupton et al., 2018):

I think you'll be ploughing a lonely burrow if you weren't able to connect with people in that way you know ... I like the conversational aspect of something like Twitter.

Maurice and Ben had created identities as educators on Twitter. However, Paul's lack of social presence on Twitter inhibited his identity and hindered the development of relationships and belonging to online communities.

\section{Capacity to participate on academic twitter}

Ben and Maurice viewed questioning and debate as important for academic practice:

Ben: I'm sure debate develops our own understanding of whatever is being presented.

Both were confident expressing critical views and participating in academic discussions on Twitter, a practice considered vitally important to the professional learning process.

However, while Matt was accustomed to posting online and making social connections on Twitter, he was reluctant to use Twitter to question or critique opinions. Similarly, Louise was hesitant to post differences of opinion online as it could be perceived as vilification of others:

It's not good to be negative, really is it? And particularly to do it in written form. I would be very hesitant to give criticism, even constructive criticism online. I'd be very slow.

Both Matt and Louise preferred to be agreeable on Twitter, even though this could be critiqued as unquestioningly echoing the sentiments of others (Rheingold, 2010). On the other hand, Ben perceived that academic debate could happen on Twitter in respectful ways if academics had the appropriate skills and conventions to communicate online in constructively critical ways. 
Other researchers in this area suggest there is much preparation needed to build the capacity of staff to participate on social networking sites (Beetham, 2015; Devine, 2015; JISC, 2014). In this study, those who had the capacity to participate on Twitter had confidence in their professional knowledge. They had well-formed academic identities, which underpinned their confidence to express professional knowledge on Twitter. Maurice's confidence in academic knowledge and practice empowered him; on the other hand, Denise and Paul lacked confidence in their professional knowledge. Matt highlighted the need to build efficacy to participate on Twitter, which is needed for enabling staff to understand online repertoires of engagement. In sum, while identity work is core to academic development (Fitzmaurice, 2013), these data demonstrate the increasing need also to focus on how digital identity is shaped (Marshall, Barbour, \& Moore, 2018).

\section{Discussion}

This study, while small in scale and limited to a local context in Ireland, provides thought-provoking insights into the experiences of staff who use Twitter for learning. Overall, participants viewed Twitter as useful for learning about academic knowledge and practices, findings that resonate with other research (Holmes et al., 2013; Krutk \& Carpenter, 2014; McPherson et al., 2015; Skyring, 2013). However, the findings here show that while some participated overtly on Twitter, others chose not to establish social presence or engage in conversations. Consequently, this brings to light diverse modes of participation on Twitter, while uncovering reasons for varying practices.

\section{Peripheral participation in online communities}

Findings illustrate that Denise, Paul, and Carol were peripheral participants in online communities on Twitter, a mode of participation that was useful for their learning needs. Wenger (1998) holds that learning can happen through various forms of social practice. Similarly, Jenkins, Ito, \& boyd's (2016) ideas on participatory learning echo this interpretation:

At any given moment, there are many different modes of engagement: some are watching and observing, waiting to participate, while others are on the floor dancing and others are much more peripheral, watching from the balcony (Jenkins et al., 2016, pp. 6-7).

While some participants did not post on Twitter, reading the Twitter stream immersed them in and exposed them to the activities of community members, and supported their professional learning. Nonetheless, through solely peripheral modes of participation these participants did not build identity among others, marginalising themselves rather than establishing a sense of belonging among members of online Twitter communities. Thus, they relinquished opportunities to reify viewpoints and construct professional knowledge with others (Wenger, 1998).

\section{Trust and expression online}

Trust is central to thriving communities (Dochy et al., 2011), yet Paul, Denise, and Carol had not established their 'emerging identity' (Neary \& Beetham, 2015, p. 98) in the public 
and precarious Twitter environment. In addition, negative incidents experienced by Denise inhibited her establishing social presence on Twitter, reinforcing Wenger's (1998) belief that destabilising events can detrimentally affect the health of communities.

Neary and Beetham (2015) acknowledge the importance of 'vulnerability, boredom, isolation, frustration, compulsion - as well as our curiosity, excitement and professional interest' (p. 98) for online spaces. Maurice's professional confidence strengthened his participation on Twitter, but he acknowledged the hesitancy of others to express themselves online. While all of the participants valued learning from peers, it seems they felt at risk in expressing their professional selves and knowledge on Twitter. Paul, Denise, and Carol felt vulnerable when considering posting on Twitter. Certainly, online expression carries implications and risks (Beetham, 2016; Cole, 2015; Duggan, 2014; Stewart, 2016), and evidence here illustrates various tensions for professionals as they negotiate and navigate social networks. On social networking sites, contexts of expression collapse and meanings can be interpreted adversely by broader audiences (Marwick \& Boyd, 2011). To evade this problem, Denise, Paul, and Carol avoided communicating on Twitter, thus sidestepping public visibility to potential online audiences. Stewart asserts that 'participation makes us visible to others who may not know us and makes our opinions and perspectives visible to those who may know ${ }^{*} \mathrm{us}^{\star}$ but have never had to grapple with taking our opinions or positions seriously' (Stewart, 2014, p. para. 9). On the other hand, at the same time Stewart highlights how those who engage instrumentally on Twitter, without participation in communities, might not benefit from the care and responsiveness that such networks offer. Stewart asserts that participation in communities mitigates the hazards of online presence and provides online participants with opportunities for respect, hospitality, approval, and encouragement. These online virtues help develop confidence in the professional self, and enable expression and posting on sites such as Twitter.

\section{Perceptions of power}

Paul and Denise perceived a hierarchy online that inhibited their participation on Twitter. They interpreted a professional gap between themselves and others, emphasising hidden power structures that exist in online social spaces. Similarly, Singh (2015) asserts the need to be cognisant of power differences online: privilege and marginalisation created by race, gender, or positions held. Indeed, concerning gender, Neary \& Beetham declare that 'participating online feels different if you are a woman' (2015, p. 98). While Paul and Denise perceived a lack of knowledge on their part, it is possible that other factors affected their capacity to participate in Twitter and find affinity in online communities. Perhaps differences in gender and tenure contributed to their confidence and identity, and affected their capacity to present themselves and participate in online communities. While conclusions about forms of privilege on social networks fall outside the scope of this study, issues of power clearly inhibited participation on academic Twitter for some respondents.

\section{Developing confidence and identity}

Paul, a new lecturer, had not yet developed a positive and confident sense of identity as an educator, which impacted on his capacity to post on academic Twitter. By contrast, 
Ben and Maurice had established their identities within online communities, which strengthened and secured their belonging. As academic developers, it is important that our professional confidence building and identity development work (Fitzmaurice, 2013), much of which is delivered by both formal and informal professional development activities, extend into the digital realm so that we can continue to support the development of confidence, professional knowledge, and identity in an increasingly digitally and socially - networked world.

\section{Implications for academic development practice}

This small-scale study, while limited to a local context, provides much-needed insights into the experiences of higher education staff using Twitter. Previous studies have established the gains to academic practice that participation on sites such as Twitter can afford, and this research sought to clarify Twitter as an informal learning space for staff, notwithstanding varying modes of participation among staff.

There is no 'escaping the digital' (Lupton et al., 2018, p. 15), yet this study highlights reluctance to participate in online communities that social networks such as Twitter offer. While we are only beginning to come to grips with and understand social networking sites, this study provides insight into factors that inhibit participation in online communities offered by Twitter. A key finding is that we need further thinking and discussion about managing the risks and benefits for staff on social networking sites (Pasquini, Wakefield, \& Roman, 2014; Rinaldo et al., 2011; Stewart, 2014). Indeed, Stewart (2016) questions whether we are mindful enough of the situations into which staff and students place themselves when using Twitter for learning and educational purposes.

Although staff may at times feel compelled to use social networks such as Twitter, this research shows that many feel underprepared for the task. If sites such as Twitter are to become widely adopted in academic practice, then the field of academic development needs to widen the scope of practice to include the development of digital capacity, so that staff can navigate and participate on social networking sites while building professional confidence and identity. Moreover, it is important that critical discussion should lead to development through greater understanding of social networks and what they mean for academic practice.

Undoubtedly, the scope of academic development work is evolving. While academic developers are responsible for supporting higher education professionals in relation to, among other things, increased confidence and engagement in critical thinking, we also need approaches that support the growth of the digital academic. These approaches should be aligned with current professional development offerings so as to include more advanced forms of digital capacity building, thereby supporting appropriate conventions and practices for online engagement while shaping the identities of digital academics.

\section{Disclosure statement}

No potential conflict of interest was reported by the author. 


\section{Notes on contributor}

Muireann O'Keeffe is an academic developer at Dublin Institute of Technology (DIT), Ireland, where she coordinates the Postgraduate Diploma in Third Level Learning and Teaching. She has worked in Universities in Ireland and Scotland in eLearning and academic development roles and has taught various courses on teaching, learning, and assessment, as well as previously coordinating a Master's in Applied eLearning. Her research interests are in educational technology and more recently, for her doctorate she took a critical interest in the use of social media for academic development.

\section{ORCID}

Muireann O’Keeffe (DD http://orcid.org/0000-0002-8093-1029

\section{References}

Beckingham, S. (2015). What is Twitter? Retrieved December 12, 2015, from http://socialmedia forlearning.com/twitter/.

Beetham, H. (2015, June 11). Revisiting digital capability for 2015. [Web log post]. Retrieved March, 2016, from https://digitalcapability.jiscinvolve.org/wp/2015/06/11/revisiting-digitalcapability-for-2015/

Beetham, H. (2016, March 24). What is 'digital wellbeing'? Retrieved April 2, 2016, from http:// design-4-learning.blogspot.ie/2016/03/what-is-digital-wellbeing.html

Bergold, J., \& Thomas, S. (2012, January). Participatory research methods: A methodological approach in motion. Retrieved May 21, 2015, from http://www.qualitative-research.net/index. $\mathrm{php} /$ fqs/article/view/1801/3334

Biesta, G. (2007). Why "what works" won't work: Evidence-based practice and the democratic deficit in educational research. Educational Theory, 57(1), 1-22.

Boon, S., Matthew, B., \& Sheward, L. (2010). Creating a profession: Building careers in educational development. (SEDA Special; no. 27). Staff and Educational Development Association (SEDA).

Boyd, D. (2009, November 29). Spectacle at Web2.0 Expo... from my perspective. [Web log post]. Retrieved from http://www.zephoria.org/thoughts/archives/2009/11/24/spectacle_at_we.html

Boyd, D. (2014). Social network sites as networked publics: Affordances, dynamics, and implications. In Z. Papcharissi (Ed.), A networked self (pp. 39-58). New York: Routledge.

Braun, V., \& Clarke, V. (2006). Using thematic analysis in psychology. Qualitative Research in Psychology, 3(2), 77-101.

Carpenter, J., \& Krutka, D. (2014). How and why educators use Twitter: A survey of the field. Journal of Research on Technology in Education, 46(4), 414-434.

Cole, K. (2015). 'It's like she's eager to be verbally abused': Twitter, trolls, and (en)gendering disciplinary rhetoric. Feminist Media Studies, 15(2), 356-358.

Costa, C. (2013). The habitus of digital scholars. Research in Learning Technology, 21(21274). doi:10.3402/rlt.v21i0.21274

Costa, C. (2014, April 28). The web and the academic divide. Retrieved November 30, 2014, from http://socialtheoryapplied.com/2014/04/28/web-academic-divide/.

Devine, J. (2015). Strategic and leadership perspectives on digital capacity in Irish higher education. Dublin: National Forum for the Enhancement of Teaching \& Learning in Higher Education. Retrieved February, 2015, from https://www.teachingandlearning.ie/wp-content /uploads/2014/03/Senior-Management-FINAL.pdf

Dochy, F., Gijbels, D., Segers, M., \& Van Den Bossche, P. (2011). Theories of learning for the workplace: Building blocks for training and professional development programs. Oxon: Routledge. 
Duggan, M. (2014, October 22). Online harassment. Retrieved October, 2015, from http://www. pewinternet.org/2014/10/22/online-harassment.

Eraut, M. (1994). Developing professional knowledge and competence. Oxon: Routledge.

Fitzmaurice, M. (2013). Constructing professional identity as a new academic: A moral endeavour. Studies in Higher Education, 38(4), 613-622.

Fransman, J. (2013). Researching academic literacy practices around Twitter: Performative methods and their onto-ethical implications. In R. Goodfellow \& M. Lea (Eds.), Literacy in the digital university: Critical perspectives on learning, scholarship, and technology (pp. 27-41). London: Routledge.

Gerstein, J. (2011). The use of Twitter for professional growth and development. International Journal on E-Learning, 10(3), 273-276. Retrieved April 18, 2016, from https://www.learnte chlib.org/p/33110/

Gibbs, G. (2013). Reflections on the changing nature of educational development. International Journal for Academic Development, 18(1), 4-14.

Higgs, B., \& McCarthy, M. (2008). The changing roles and identities of teachers and learners in higher education in Ireland: An introduction. In B. Higgs \& M. McCarthy (Eds.), Emerging Issues 2 (pp. 1-9). Dublin: EDIN.

Holmes, K., Preston, G., Shaw, K., \& Buchanan, R. (2013, August). 'Follow' me: Networked professional learning for teachers. Australian Journal of Teacher Education, 38(12). doi:10.14221/ajte.2013v38n12.4

Hughes, G. (2010). Identity and belonging in social learning groups: The importance of distinguishing social, operational and knowledge-related identity congruence. British Educational Research Journal, 36(1), 47-63.

Jenkins, H., Ito, M., \& Boyd, D. (2016). Participatory culture in a networked era: A conversation on youth, learning, commerce, and politics. Cambridge: Polity Press.

JISC. (2014). Building capability for new digital leadership, pedagogy and efficiency. Retrieved March, 2016, from https://www.jisc.ac.uk/rd/projects/building-digital-capability

Krutk, D., \& Carpenter, J. (2014). Engagement through microblogging: Educator professional development via Twitter. Professional Development in Education, 41(4), 707-728.

Leibowitz, B. $(2014,4)$. Reflections on academic development: What is in a name? International Journal for Academic Development, 19(4), 357-360.

Linder, K. E., \& Felten, P. (2015). Understanding the work of academic development. International Journal for Academic Development, 20(1), 1-3.

Lupton, D. (2014). 'Feeling better connected': Academics' use of social media. News \& Media Research Centre. Canberra: University of Canberra. Retrieved February 23, 2015, from http:// apo.org.au/system/files/53908/apo-nid53908-48756.pdf.

Lupton, D., Mewburn, I., \& Thomson, P. (2018). The digital academic: Identities, contexts and politics. In D. Lupton, I. Mewburn, \& P. Thomson (Eds.), The digital academic (pp. 1-19). Oxon: Routledge.

Marshall, P., Barbour, K., \& Moore, C. (2018). Academic Persona: The construction of online reputation in the modern academy. In D. Lupton, I. Mewburn, \& P. Thomson (Eds.), The digital academic (pp. 47-62). Oxon: Routledge.

Marsick, V. J., \& Watkins, K. (1990). Informal and incidental learning in the workplace. London: Routledge.

Mårtensson, K., \& Roxå, T. (2015). Academic development in a world of informal learning about teaching and student learning. International Journal for Academic Development, 20(2), 109-112.

Marwick, A., \& Boyd, D. (2011). I tweet honestly, I tweet passionately: Twitter users, context collapse, and the imagined audience. New Media and Society, 13(1), 114-133.

McPherson, M., Budge, K., \& Lemon, N. (2015). New practices in doing academic development: Twitter as an informal learning space. International Journal for Academic Development, 20(2), 126-136.

Miles, M., Huberman, A., \& Saldana, J. (2014). Qualitative data analysis a methods sourcebook (3rd ed.). London: Sage. 
National Forum. (2015). Mapping professional development pathways for those who teach in Irish higher education: Where are we now and where do we want to go? Dublin: Author. Retrieved March 26, 2015, from https://www.teachingandlearning.ie/wp-content/uploads/2015/03/ Mapping-PD-SUMMARY.pdf

Neary, M., \& Beetham, H. (2015). The nature of academic space. In J. Lea (Ed.), Enhancing learning and teaching in higher education: Engaging with the dimensions of practice (pp. 83-102). Maidenhead: Open University Press.

O’Keeffe, M. B. (2016, October 28). Exploring higher education professionals' use of Twitter for learning. UCL Discovery, Retrieved February 23, 2017, from http://discovery.ucl.ac.uk/ 1521971/.

Oliver, M. (2013). Learning technology: Theorising the tools we study. British Journal of Educational Technology, 44(1), 31-43.

Pasquini, L. (2015, April 9). Twitter to enhance learning \& performance. [Web log post].Retrieved April 20, 2015, from https://techknowtools.wordpress.com/2015/04/09/twitter-learningperformance/.

Pasquini, L., Wakefield, J., \& Roman, T. (2014, November). Impact factor: Early career research \& digital scholarship. TechTrends: Linking Research \& Practice to Improve Learning., 58(6), $12-13$.

Pearce, N., Weller, M., Scanlon, E., \& Kinsley, S. (2010). Digital scholarship considered: How new technologies could transform academic work. In Education, 16(1), Retrieved from http:// ineducation.ca/ineducation/article/view/44

Rheingold, H. (2010). Attention, and other 21st-century social media literacies. EDUCAUSE Review, 45(5), 14-24. Retrieved April 20, 2013, from https://er.educause.edu/articles/2010/10/ attention-and-other-21stcentury-social-media-literacies

Rienties, B., \& Hosein, A. (2015). Unpacking (in)formal learning in an academic development programme: A mixed-method social network perspective. International Journal for Academic Development, 20(2), 163-177.

Rinaldo, S., Tapp, S., \& Laverie, D. (2011, July). Learning by tweeting: Using Twitter as a pedagogical tool. Journal of Marketing Education, 33(2), 193-203.

Selwyn, N. (2013). Education in a digital world: Global perspectives on technology and education. New York: Routledge.

Singh, S. (2015, June 27). The fallacy of 'open'. [Web log post]. Retrieved May 20, 2016, from https://savasavasava.wordpress.com/2015/06/27/the-fallacy-of-open/.

Skyring, C. (2013). Learning in 140 characters: Microblogging for professional learning (Doctoral dissertation). Queensland University of Technology, Faculty of Education, Brisbane. Retrieved February 20, 2015, from https://eprints.qut.edu.au/65854/1/Carol_Skyring_Thesis.pdf

Slowey, M., Kozina, E., \& Tan, E. (2014). Voices of academics in Irish higher education. Perspectives on professional development. Dublin: AISHE. Retrieved November 20, 2014, from http://www.aishe.org/wp-content/uploads/2012/01/Voices-of-Academics-in-HE.pdf

Stewart, B. (2014, November 4). Networks of care and vulnerability. [Web log post]. the theoryblog Retrieved from http://theory.cribchronicles.com/2014/11/04/networks-of-care-and -vulnerability/

Stewart, B. (2015). Open to influence: What counts as academic influence in scholarly networked Twitter participation. Learning, Media and Technology, 40(3), 287-309.

Stewart, B. (2016, January). Academic Twitter: The intersection of orality \& literacy in scholarship? [Video file]. Retrieved from https://youtu.be/e4RSaG2iVKk.

Veletsianos, G. (2012). Higher education scholars' participation and practices on Twitter. Journal of Computer Assisted Learning, 28, 336-349.

Veletsianos, G., \& Kimmons, R. (2012). Networked participatory scholarship: Emergent techno-cultural pressures toward open and digital scholarship in online networks. Computers \& Education, 58(2), 766-774.

Wenger, E. (1998). Communities of practice: Learning, meaning, and identity. Cambridge: Cambridge University Press. 